\title{
Circulation of Dirofilaria repens and Dirofilaria immitis in Moldova
}

Tatiana Șuleșco ${ }^{1}$, Heidrun von Thien ${ }^{2}$, Lidia Toderaș ${ }^{1}$, Ion Toderaș ${ }^{1}$, Renke Lühken ${ }^{2 *}$ and Egbert Tannich ${ }^{2,3}$

\begin{abstract}
Background: Over the last two decades, a significant spread of dirofilariasis has been observed in eastern and central Europe. However, data on the circulation of Dirofilaria spp. in Moldova were absent although direct neighbor states reported high incidence rates of human dirofilariasis.

Methods: Daily mean temperature data were used to calculate Dirofilaria spp. development units, which were used to estimate the potential for complete extrinsic development in the mosquitoes (= sum of potential Dirofilaria spp. transmission days). In addition, 4,481 adult female mosquitoes were collected from 25 trapping sites. From 2010 to 2015, sampling was conducted with Centers for Disease Control miniature light traps, indoor resting mosquito collections as well as human landing catches in urban, rural and natural areas. Mosquitoes were analyzed for the presence of $D$. repens and $D$. immitis DNA using a duplex real-time PCR assay targeting nucleotide differences within the cytochrome c oxidase subunit 1 (D. repens) and 165 rRNA gene fragment (D. immitis).

Results: The average of the yearly sum of potential Dirofilaria spp. transmission days between 2010 and 2015 ranged from 90 to 140 days with an increasing gradient from the North to the South of Moldova. Positive mosquito pools for $D$. repens were found countrywide at 13 of the 25 trapping sites and in 17 of the 22 screened mosquito taxa (26.51\% of all 347 tested pools), while D. immitis was detected only at 4 of the trapping sites (Center and South) in 4 different mosquito species (8.65\% of all 347 tested pools). Highest infection rates (EIR) per 100 specimens for both Dirofilaria species were found in An. maculipennis (s.l.) (D. repens: $E I R=4.91$; D. immitis: $E I R=2.01$ ), whereas the most frequent mosquito taxon $C$. pipiens (s.l.)/torrentium had significantly lower infections rates (D. repens: $\mathrm{EIR}=0.88$; D. immitis: $\mathrm{EIR}=0.47$ ).

Conclusions: The temperature conditions in Moldova are suitable for transmission of Dirofilaria spp. within the entire country, which is supported by a wide distribution of Dirofilaria spp.-positive mosquitoes with high infection rates. The low number of reported human cases most likely does not reflect the current epidemiological situation of dirofilariasis in Moldova.
\end{abstract}

Keywords: Dirofilaria repens, Dirofilaria immitis, Vectors, Dirofilaria development units

\section{Background}

Nematodes of the genus Dirofilaria (Spirurida: Onchocercidae) are mosquito-borne parasites, infecting wild and domestic mammals of different orders with canids as predominant definitive host [1]. In Europe, D. repens Railliet \& Henry, 1911 and D. immitis (Leidy, 1856) are the causative agents of dirofilariasis [2]. With few exceptions [3-8], humans are dead-end hosts for the parasites

\footnotetext{
* Correspondence: renkeluhken@gmail.com

${ }^{2}$ Bernhard Nocht Institute for Tropical Medicine, WHO Collaborating Centre for Arbovirus and Hemorrhagic Fever Reference and Research, Hamburg, Germany

Full list of author information is available at the end of the article
}

as they usually do not develop to the fertile adult stage, but infections can result in pulmonary and subcutaneous nodules. However, in rare cases, severe clinical manifestations affecting various organs have been reported $[3,9]$.

Over the last two decades, a significant spread of human Dirofilaria spp. infections has been observed in eastern and central Europe, including an increase of human cases $[10,11]$. Moreover, autochthonous cases were detected in countries, which were previously regarded as non-endemic: Austria [12], Poland [13], Germany [14], Czech Republic [15] and Belarus [16]). Moldova is 
bordered to the East and South by the Odessa region of the Ukraine where incidence rates for human dirofilariasis ranged from 2.43 to 3.71 per 100,000 inhabitants between 1997 and 2012 [10]. In the eastern neighbor state Romania, at least 12 autochthonous human cases were detected since 2009 and nearly all cases were reported from southern and eastern parts of the country, close to the border with Moldova [17-19]. However, precise information on the prevalence of Dirofilaria spp. in Moldova does not exist. Due to the lack of diagnostic capacities and the low awareness of physicians, human cases of dirofilariasis are usually detected by chance and the few published case reports probably do not reflect the current epidemiological situation in the country. Only five cases of human dirofilariasis have been reported so far. The first documented autochthonous human case has been detected in Hincesti (central Moldova) in 1968 [20]. Three autochthonous human cases of ocular dirofilariasis were reported from Tiraspol (2000), Chisinau (2007) and Bender (2009) in eastern and central Moldova [21, 22]. In 2011, the most recent clinical case of subcutaneous dirofilariasis has been described, but from the case description it is unclear whether the patient resided in Moldova and whether this case was autochthonous or imported [23]. Species identification of the isolated nematodes from subcutaneous or ocular lesions was based on microscopic evaluation of morphological characters only. In addition, there are hardly any studies evaluating Dirofilaria spp. infections in the local canine populations and only one recent study reports the presence of $D$. immitis identified by morphology in $24 \%$ of examined dogs from central Moldova, indicating circulation of the parasite at least in this part of the country [24].

Due to the lack of a systematic xenomonitoring of dogs, humans or mosquitoes, the prevalence and risk of Dirofilaria spp. transmission in Moldova is unknown. Therefore, in a first step, Dirofilaria spp. transmission days were calculated on the base of daily mean temperature data to assess the nationwide potential risk of transmission. In addition, a molecular screening of field-collected mosquitoes was performed to confirm circulation of $D$. repens and $D$. immitis, to identify potential mosquito vector species, and to get information about the spatial-temporal distribution of both parasite species. Furthermore, the study was used to compare the Dirofilaria spp. screening results between the three trapping methods used, i.e. Centers for Disease Control miniature light traps (CDC traps), indoor resting mosquito collections and human landing catches.

\section{Methods}

\section{Mosquito sampling and species identification}

Within a countrywide field survey, adult mosquitoes were collected from 25 trapping sites in Moldova (Fig. 1). Sampling was performed between 2010 and 2015 in urban, rural and natural areas using CDC traps (model 512, John W. Hock Company, Gainesville, Florida, USA), indoor resting mosquito collections with mouth aspirators and human landing catches (see Șuleșco et al. [25] for further methodological details). Furthermore, one site representative for the rural areas in the southern steppe zone in Moldova has been selected for systematic mosquito collections in the years 2014 and 2015 (Ceadir-Lunga, WGS84 coordinates: 46.06549 N, 28.84219E). Between June and October, two CDC traps were operated and regular collections of indoor resting mosquitoes and human landing catches were conducted. Mosquitoes were transported to the laboratory alive and killed in a freezer at $-20{ }^{\circ} \mathrm{C}$ for approximately $3-10 \mathrm{~min}$. Mosquitoes were identified to species or species complex according to the taxonomic keys published by Schaffner et al. [26] and Becker et al. [27].

\section{Molecular Dirofilaria spp. screening}

Female mosquito specimens were screened for D. repens and D. immitis [16]. Mosquitoes were pooled by sampling site, sampling date and taxon comprising between 1 to 35 specimens per pool $($ mean $=12.91)$ and stored in $96 \%$ ethanol until further processing. For DNA extraction, mosquitoes were placed in sterile $2 \mathrm{ml}$ reaction tubes and $1 \mathrm{ml}$ of cell culture medium (high-glucose Dulbecco's modified Eagle's medium (Sigma-Aldrich, St. Louis, USA) with $10 \%$ heat-inactivated fetal bovine serum, $100 \mathrm{U} / \mathrm{ml}$ penicillin, $100 \mu \mathrm{g} / \mathrm{ml}$ streptomycin, and $2.5 \mu \mathrm{g} / \mathrm{ml}$ amphotericin B) and 2 stainless steel beads with a diameter of $5.0 \mathrm{~mm}$ were added for homogenization in a TissueLyser (Qiagen, Hilden, Germany) at 50 oscillation/s for $2 \mathrm{~min}$. The suspensions were clarified by centrifugation $(13,000 \times g$ for $5 \mathrm{~min})$, and the supernatant was used for DNA extraction with the MagMAX ${ }^{\mathrm{Tm}}$ Pathogen RNA/DNA Kit using the MagMAX ${ }^{\text {su }}$ Express-96 Deep Well Magnetic Particle Processor (Thermo Fisher Scientific Inc., Waltham, USA) according to the manufacturer's protocol. The extracted DNA of each sample was analyzed by quantitative real-time PCR (qPCR) assays for the detection of $D$. repens or D. immitis DNA. A cytochrome $c$ oxidase subunit 1 gene fragment of $D$. repens was amplified using the primers RepF (5'-GAG ATG GCG TTT CCT CGT G-3') and RepR (5'-GAC CAT CAA CAC TTA AAG-3') and the probe RepT (5'-JOE-GTT GCT TTG TTA ATG GTT TAT C-BHQ1-3'; JOE = 6-carboxy-4', 5' -dichloro-2', $7^{\prime}$ dimethoxyfluorescein, BHQ1 = black hole quencher 1). For D. immitis, a 16S rRNA gene fragment was amplified using the primers ImmF (5'-CTA TAT GTT ACC TTA ATT GG-3') and ImmR (5'-CTT AAC CAT TAT CTT AGA TCA G-3') and the probe ImmT (5'-ROX-GTA GCT AGT AAG TTT ACC TTG-BHQ2-3'; ROX =6-carboxy-Xrhodamine, $\mathrm{BHQ} 2$ = black hole quencher 2 ). The PCRs were performed with the Rotor-Gene ${ }^{\mathrm{mm}} 6000$ real-time 


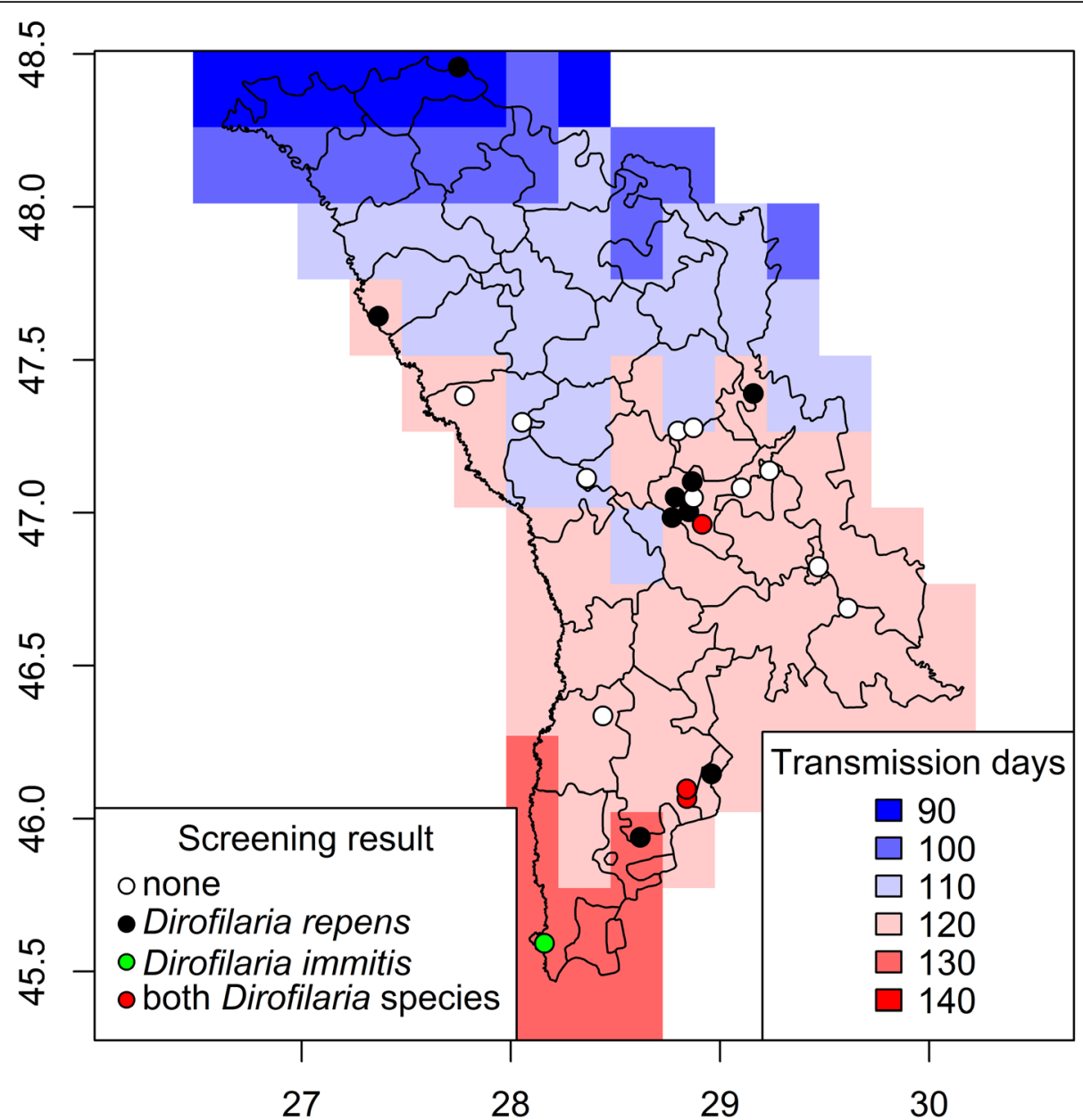

Fig. 1 Average of the yearly sum of potential Dirofilaria spp. transmission days in Moldova (2010 and 2015) with information on the mosquito sampling sites and Dirofilaria spp. screening results

PCR machine (Corbett Research, Sydney, Australia). The reaction mixture $(20 \mu \mathrm{l})$ contained $10 \mu \mathrm{l}$ of $2 \times$ HotStartTaq Plus Master Mix Kit (Qiagen, Hilden, Germany), $25 \mathrm{mM} \mathrm{MgCl} 2,16$ pmol RepT or $0.8 \mathrm{pmol}$ ImmT, $1 \mathrm{mg} / \mathrm{ml} \mathrm{BSA}, 4 \mathrm{pmol}$ and $24 \mathrm{pmol}$ of each ImmF / ImmR or RepF / RepR primer pairs, respectively, and $2 \mu \mathrm{l}$ of extracted DNA (except nontemplate controls). The thermo profile included an initial denaturation of $15 \mathrm{~min}$ at $95{ }^{\circ} \mathrm{C}$ followed by 50 cycles consisting of $15 \mathrm{~s}$ denaturation at $95{ }^{\circ} \mathrm{C}$, $30 \mathrm{~s}$ of annealing at $61{ }^{\circ} \mathrm{C}$ and elongation of $30 \mathrm{~s}$ at $72{ }^{\circ} \mathrm{C}$. The PCR ended with a final step of $30 \mathrm{~s}$ at $40{ }^{\circ} \mathrm{C}$. Fluorescence signals were measured during each extension phase of the PCR reactions and finally analyzed with the Rotor-Gene ${ }^{\mathrm{Tm}} 6000$ software version 6.1.8.1. (Corbett Research, Sydney, Australia). PCR amplicons with positive signals in the $\mathrm{qPCR}$ were subjected to DNA sequencing on both strands using the same sets of primers that were used in the qPCR. Sequences were edited and aligned using MacVector software version 14.5 (MacVector, Inc., Cambridge, United Kingdom). Resulting sequences were compared with sequences available in the GenBank database.

\section{Statistical analyses}

Data analysis and visualization was conducted with the program R [28] using the packages ggplot2 [29], plyr [30], maptools [31], raster [32] and rgeos [33]. With the same calculation method used in other studies [34], Dirofilaria spp. development units (DDUs) were calculated on the base of daily mean temperature data on a $0.25^{\circ}$ regular latitude-longitude grid downloaded from http:// www.ecad.eu/ [35]. For each grid cell, the daily sums of temperature degrees above a $14{ }^{\circ} \mathrm{C}$ threshold within 30 preceding days (corresponding to the estimated mosquito life span maximum) were computed on the base of the mean daily temperatures between April 1 and October 15 (potential mosquito activity season). Days with a sum of DDUs larger 130 were considered to allow extrinsic development of infective larvae in the mosquitoes 
and summed for each grid cell and year (= sum of potential Dirofilaria spp. transmission days) and finally averaged over the years of the sampling period (20102015).

Estimated infection rates (EIRs) with corresponding 95\% confidence intervals (95\% CI) were calculated over all analyzed pools per mosquito species and Dirofilaria species using the binGroup package [36]. Point estimates were calculated with biased-corrected maximum likelihood estimation and confidence intervals were skewness-corrected. Non-overlapping confidence intervals were interpreted as a significant difference.

\section{Results}

The average of the yearly sum of potential Dirofilaria spp. transmission days between 2010 and 2015 ranged from 90 to 140 days with an increasing gradient from the North to the South (Fig. 1). Dirofilaria spp.-infected mosquitoes were found in 14 of the 25 trapping sites analyzed. Dirofilaria repens had a wide distribution and occurred in all parts of the country at 13 out of 25 trapping sites $(52.00 \%)$. In contrast, D. immitis was only registered at four trapping sites $(16.00 \%)$ in central and southern Moldova, but not in the northern part of the country. There were no differences in the average sum of potential Dirofilaria spp. transmission days between sampling sites that were positive for $D$. immitis $(120.87 \pm 7.76)$ or $D$. repens $(121.54 \pm 10.09)$.

In total, the survey analyzed 22 mosquito taxa $(4,481$ specimens) belonging to six genera (Aedes, Anopheles, Coquillettidia, Culex, Culiseta and Uranotaenia). All of them were screened for the presence of $D$. repens and $D$. immitis DNA (Table 1). Culex pipiens (s.l.)/torrentium was the most frequent species examined (59.43\%), followed by An. maculipennis (s.l.) (21.13\%), Ae. vexans (7.01\%) and Cx. modestus (4.53\%). A total of 347 mosquito pools was screened and 109 pools $(31.41 \%)$ tested positive (EIR per 100 specimens $=2.89$, 95\% CI: $2.41-$ 3.44). Ninety-two pools (26.51\%) were positive for $D$. repens $(\mathrm{EIR}=2.34,95 \%$ CI: $1.92-2.84)$ whereas 30 pools (8.65\%) were positive for D. immitis DNA (EIR $=0.71$, 95\% CI: $0.49-0.99)$. In addition, 13 pools (3.75\%) were tested positive for both Dirofilaria species.

Dirofilaria repens was detected for 17 of the 22 screened mosquito taxa, while $D$. immitis was only found for 4 mosquito taxa (Table 1). The highest EIRs (mean between 50 and 100) were observed for the species represented in small sample sizes (e.g. Ae. flavescens, An. pseudopictus or Cs. longiareolata), though EIR based on small sample sizes do not accurately represent the true infection rate in the population [37]. For mosquito taxa represented by larger sample sizes ( $>100$ specimens), highest EIRs for both Dirofilaria species were found for An. maculipennis (s.l.) (D. repens: $\mathrm{EIR}=4.91$,
95\% CI: 3.43-6.95; D. immitis: EIR $=2.01,95 \%$ CI: 1.20 3.20 ), whereas the most frequent mosquito taxon $C x$. pipiens (s.l.)/torrentium had significantly lower infections rates for both nematode species as indicated by nonoverlapping confidence intervals $(D$. repens: $\mathrm{EIR}=0.88$, 95\% CI: 0.57-1.30; D. immitis: $\mathrm{EIR}=0.47,95 \%$ CI: $0.25-$ $0.79)$.

Dirofilaria spp.-positive mosquito pools were detected in each of the 6 study years between May and September (Fig. 2). The highest number of positive pools for both Dirofilaria species was recognized in August (44.04\% of 109 pools) comprising $29.36 \%$ of all tested pools positive for $D$. repens and $14.68 \%$ positive for $D$. immitis.

The number of mosquito specimens and the composition of mosquito species differed between the three sampling methods (Fig. 3). A total of 4,481 mosquito specimens $(58.87 \%$ of the specimens, 12 mosquito taxa, $54.55 \%$ of all collected mosquito taxa) were captured by CDC traps. Mosquito indoor resting collections and human landing catches represented 29.81\% (15 mosquito taxa, $68.18 \%$ ) and $11.31 \%$ (9 mosquito taxa, $40.91 \%$ ) of all mosquito specimens, respectively. The prevalence of both Dirofilaria species did not show significant differences between the three trapping methods, but the infection rates for $D$. repens were significantly higher for the mosquitoes sampled with CDC traps and human landing catches compared to the collections of indoor resting mosquitoes (Table 2).

\section{Discussion}

Various epidemiological studies in Europe report a geographical spread of Dirofilaria spp. in eastern and central Europe [10-16]. However, information on the risk of Dirofilaria spp. transmission in Moldova is scarce and only few recent studies reported dirofilariasis in dogs [24] or humans [21-23]. Nevertheless, the mean daily temperatures between 2010 and 2015, as analyzed in this study, indicate a potential risk of Dirofilaria spp. transmission for the entire country, which is confirmed by the wide distribution of Dirofilaria spp--positive mosquitoes with high infection rates. Thus, this study gives clear molecular evidence for the circulation of Dirofilaria spp. and identified several potential mosquito vector species in Moldova, which until recently was considered a non-endemic country.

Of the 36 mosquito species currently known for Moldova [25], 22 mosquito taxa (61.11\%) were included in the Dirofilaria spp. screening. Our findings suggest that various mosquito species of the genera Aedes, Anopheles, Culex and Coquillettidia probably take part in the transmission of Dirofilaria spp. in Moldova. Pools of 17 different mosquito taxa $(47.22 \%$ of the currently known species) were tested positive, which indicates a broad spectrum of potential vector species for 
Table 1 Mosquito taxa collected in Moldova between 2010 and 2015 with information on the number of screened mosquito specimens, tested pools, Dirofilaria spp. screening results and estimated infection rates (EIR) per 100 mosquito specimens with corresponding 95\% confidence intervals (95\% CI)

\begin{tabular}{|c|c|c|c|c|c|c|c|}
\hline Mosquito species & $\begin{array}{l}\text { No. of mosquito } \\
\text { specimens }\end{array}$ & No. of pools & $\begin{array}{l}\text { No. of positive pools } \\
\text { (\% of tested pools } \\
\text { per species) }\end{array}$ & $\begin{array}{l}\text { No. of } D \text {. repens-positive } \\
\text { pools (\% of tested } \\
\text { pools per species) }\end{array}$ & EIR $(95 \% \mathrm{Cl})$ & $\begin{array}{l}\text { No. of D. immitis-positive } \\
\text { pools (\% of tested } \\
\text { pools per species) }\end{array}$ & $\operatorname{EIR}(95 \% \mathrm{Cl})$ \\
\hline Culex pipiens (s.l.)/torrentium & 2,663 & 132 & $32(24.24)$ & $22(16.66)$ & $0.88(0.57-1.30)$ & $12(9.09)$ & $0.47(0.25-0.79)$ \\
\hline Anopheles maculipennis (s.l.) & 947 & 62 & $37(59.67)$ & $31(50.00)$ & $4.91(3.43-6.95)$ & $16(25.80)$ & $2.01(1.20-3.20)$ \\
\hline Aedes vexans & 314 & 33 & $5(15.15)$ & $5(15.15)$ & $1.68(0.65-3.68)$ & $0(0)$ & $0(-)$ \\
\hline Culex modestus & 203 & 25 & $6(24.00)$ & $6(24.00)$ & $3.26(1.45-6.60)$ & $0(0)$ & $0(-)$ \\
\hline Uranotaenia unguiculata & 119 & 8 & $1(12.50)$ & $1(12.50)$ & $0.81(0.05-3.94)$ & $0(0)$ & $0(-)$ \\
\hline Aedes annulipes & 51 & 10 & $3(30.00)$ & $3(30.00)$ & $6.96(2.06-19.19)$ & $0(0)$ & $0(-)$ \\
\hline Culiseta annulata & 38 & 13 & $4(30.76)$ & $4(30.76)$ & $11.34(4.02-25.12)$ & $0(0)$ & $0(-)$ \\
\hline Aedes caspius & 26 & 13 & $6(46.15)$ & $6(46.15)$ & $22.64(11.15-39.32)$ & $0(0)$ & $0(-)$ \\
\hline Aedes geniculatus & 26 & 10 & $2(20.00)$ & $2(20.00)$ & $7.45(1.47-21.85)$ & $0(0)$ & $0(-)$ \\
\hline Aedes sticticus & 24 & 7 & $1(14.28)$ & $1(14.28)$ & $4.43(0.26-20.71)$ & $0(0)$ & $0(-)$ \\
\hline Coquillettidia richiardii & 19 & 11 & $3(27.27)$ & $3(27.27)$ & $16.25(4.64-37.89)$ & $0(0)$ & $0(-)$ \\
\hline Aedes cantans & 15 & 5 & $2(40.00)$ & $2(40.00)$ & $14.84(2.87-43.95)$ & $0(0)$ & $0(-)$ \\
\hline Aedes riparius & 9 & 4 & $2(50.00)$ & $2(50.00)$ & $31.20(6.08-84.92)$ & $0(0)$ & $0(-)$ \\
\hline Aedes dorsalis & 7 & 1 & $0(0)$ & $0(0)$ & $0(-)$ & $0(0)$ & $0(-)$ \\
\hline Anopheles plumbeus & 4 & 2 & $0(0)$ & $0(0)$ & $0(-)$ & $0(0)$ & $0(-)$ \\
\hline Culiseta longiareolata & 4 & 4 & $2(50.00)$ & $2(50.00)$ & $50.00(10.55-89.45)$ & $0(0)$ & $0(-)$ \\
\hline Aedes cataphylla & 3 & 1 & $0(0)$ & $0(0)$ & $0(-)$ & $0(0)$ & $0(-)$ \\
\hline Anopheles claviger & 3 & 1 & $0(0)$ & $0(0)$ & $0(-)$ & $0(0)$ & $0(-)$ \\
\hline Aedes behningi & 2 & 2 & $1(50.00)$ & $0(0)$ & $0(-)$ & $1(50.00)$ & $50.00(3.26-96.74)$ \\
\hline Anopheles pseudopictus & 2 & 1 & $1(100)$ & $1(100)$ & $50.00(0.00-100.00)$ & $1(100)$ & $50.00(0.00-100.00)$ \\
\hline Aedes flavescens & 1 & 1 & $1(100)$ & $1(100)$ & $100.00(100.00-100.00)$ & $0(0)$ & $0(-)$ \\
\hline Aedes cinereus/geminus & 1 & 1 & $0(0)$ & $0(0)$ & $0(-)$ & $0(0)$ & $0(-)$ \\
\hline Total & 4,481 & 347 & 109 (31.41) & $92(26.51)$ & & 30 (8.64) & \\
\hline
\end{tabular}




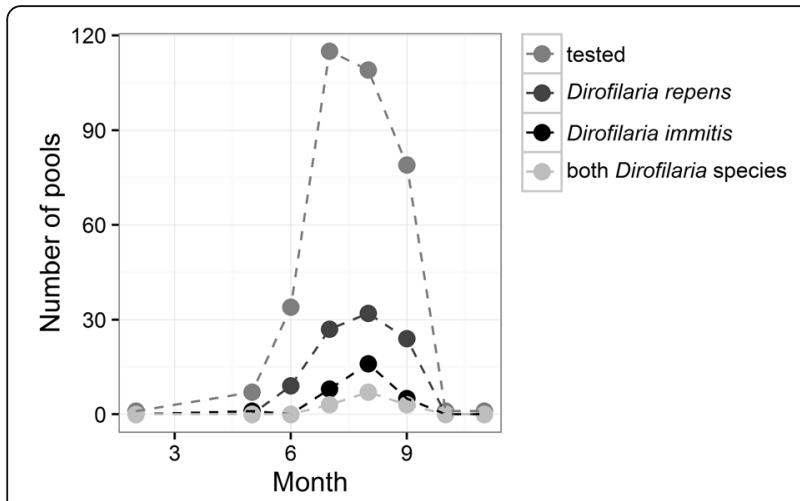

Fig. 2 Number of mosquito pools tested per month and the number of pools positive for D. repens, D. immitis or both Dirofilaria species
Dirofilaria spp. transmission in the country. Dirofilaria spp. DNA was detected in several mosquito species previously identified as potential vector species during different field-studies in Europe (Table 3). In contrast, the pools of three mosquito species, which were tested positive in previous studies, were negative in this study: Ae. dorsalis (D. repens: Hungary [38]), An. claviger (D. immitis: Belarus [16]), Ae. cinereus/geminus (D. repens: Hungary [38]). To the best of our knowledge, Dirofilaria spp. were identified for the first time in four species (Ur. unguiculata, Ae. geniculatus, Ae. cantans and Cs. longioreolata), which have not been identified as potential vectors in other European countries, where these mosquitoes were studied and dirofilariasis is endemic [38-44]. In addition, this study screened pools of six mosquito species, which were not included in previous studies in Europe. Hereby, pools of the species Ae. riparius,

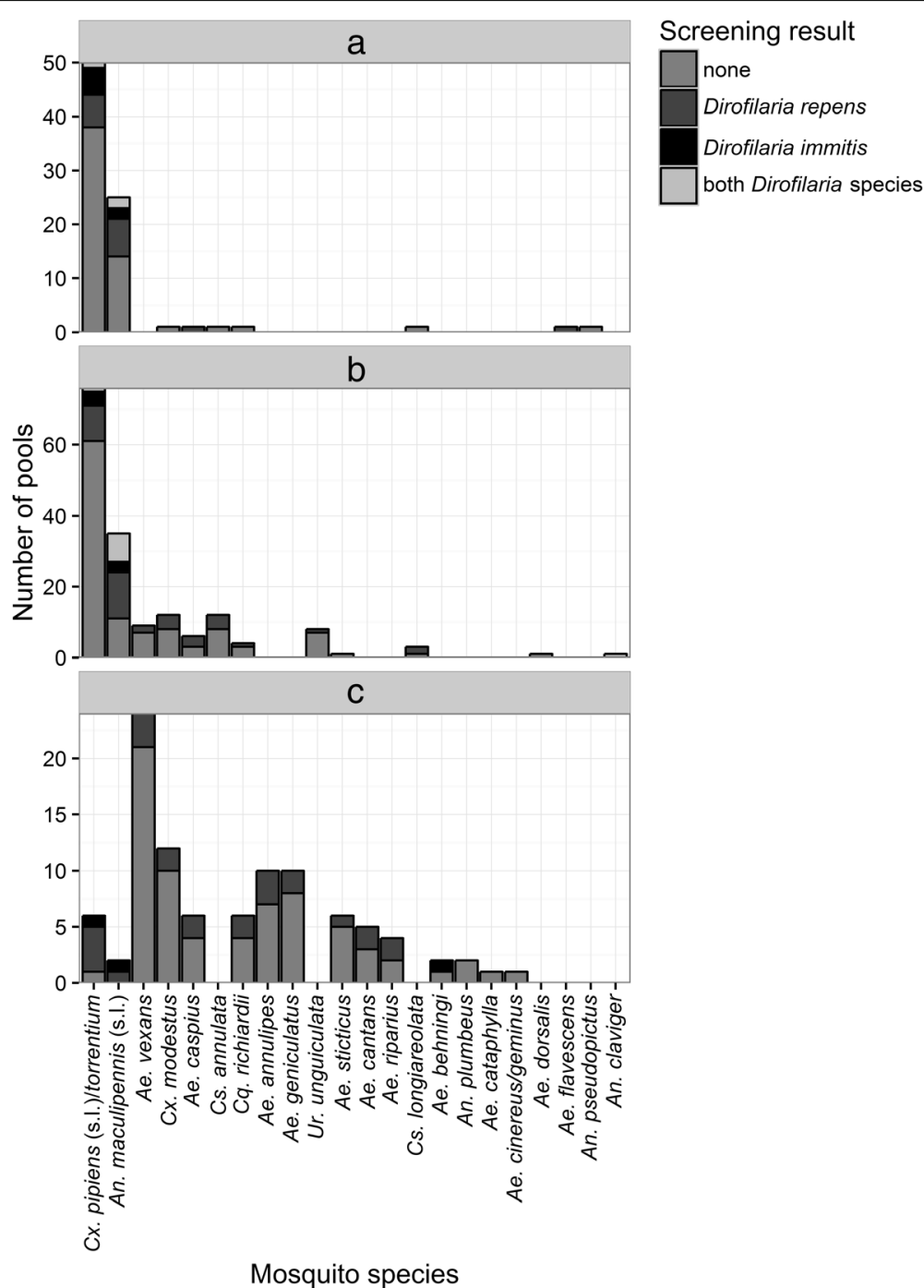

Fig. 3 Number of mosquito pools tested per mosquito species and the number of pools positive for D. repens, D. immitis or both Dirofilaria species for the three sampling methods. a Indoor resting collection $\mathbf{b}$ CDC trap $\mathbf{c}$ Human landing 
Table 2 Prevalence and estimated infection rates (EIR) of both Dirofilaria species per 100 mosquito specimens with corresponding 95\% confidence intervals (95\% Cl) for the three sampling methods

\begin{tabular}{llll}
\hline & Indoor resting mosquito collections & CDC trap & Human landing \\
\hline $\begin{array}{l}\text { No. of pools tested negative (percentage of all tested } \\
\text { pools per sampling method) }\end{array}$ & $57(69.51)$ & $111(66.07)$ & 70 (72.16) \\
$\begin{array}{l}\text { No. of pools tested positive for D. repens (percentage of } \\
\text { all tested pools per sampling method) }\end{array}$ & $15(18.29)$ & $7(4.81)$ \\
$\begin{array}{l}\text { No. of pools tested positive for D. immitis (percentage of } \\
\text { all tested pools per sampling method) }\end{array}$ & $7(8.54)$ & 24 (24.74) \\
$\begin{array}{l}\text { No. of pools tested positive for both Dirofilaria species } \\
\text { (percentage of all tested pools per sampling method) }\end{array}$ & $3(3.66)$ & $10(5.95)$ & $3(3.09)$ \\
EIR for D. repens $(95 \% \mathrm{Cl})$ & $1.33(0.82-2.05)$ & $2.98(2.26-3.86)$ & $3(0.00)$ \\
EIR for D. immitis $(95 \% \mathrm{Cl})$ & $0.69(0.35-1.21)$ & $0.89(0.54-1.40)$ & $3.03(2.05-4.35)$ \\
\hline
\end{tabular}

Ae. behningi, An. pseudopictus and Ae. flavescens were tested positive whereas pools of An. plumbeus and Ae. cataphylla tested negative for Dirofilara spp. DNA.

However, the vector competence for most of these mosquito species remains unknown. Different factors may influence the susceptibility of mosquitoes to Dirofilara spp. infections. In addition to damage of microfilariae by species-specific cibarial and pharyngeal armatures, species-specific encapsulation or melanization of the parasite can occur [45]. Furthermore, depending on the microfilarial density in the vertebrate hosts, Dirofilara spp. infections may lead to a species-specific increase of mosquito mortality $[46,47]$, e.g. through invasion of the Malphigian tubule cells [48]. In order to make a definitive assessment of the vector competence of the different mosquito species, some studies in Europe analyzed mosquito heads and abdomens separately to differentiate between infective (potential to transmit the nematode) and infected specimens (only microfilaria in its stomach), but generally did not find significant differences regarding the classification as a vector or non-vector for Dirofilaria spp. [40-42, 46, 49-51]. A final assessment of the vector competence requires infection experiments evaluating the susceptibility of the different mosquito species using different microfilarial densities of the vertebrate host under consideration of the impact of Dirofilaria spp. infections on the mosquito mortality rate [47].

Nevertheless, in Moldova, members of the taxa $A n$. maculipennis (s.l.) and Culex pipiens (s.l.)/torrentium are probably the most important Dirofilaria spp. vectors. Anopheles maculipennis (s.l.) was the second most abundant taxon with high infection rates for both Dirofilaria species. In contrast, Culex pipiens (s.l.)/torrentium had significantly lower infection rates, but had a three times higher abundance. Members of both species complexes have been previously identified as potential vectors of Dirofilaria spp. in infection experiments [52] and in field studies [41, 42, 53]. Furthermore, the collection of

Table 3 Dirofilaria spp.-positive mosquito species in Moldova between 2010 and 2015 previously identified as potential vector species during different field-studies in Europe

\begin{tabular}{|c|c|c|c|}
\hline Mosquito species & $\begin{array}{l}\text { Detected Dirofilaria species in } \\
\text { Moldavian mosquito species }\end{array}$ & $\begin{array}{l}\text { Countries with detection of } D \text {. repens } \\
\text { in the mosquito species }\end{array}$ & $\begin{array}{l}\text { Countries with detection of } D \text {. immitis } \\
\text { in the mosquito species }\end{array}$ \\
\hline Culex pipiens (s.l.)/torrentium & D. repens and D. immitis & Italy [49], Serbia [39] & $\begin{array}{l}\text { Belarus [16], Italy [40,46, 49, 58], } \\
\text { Serbia [39], Turkey [50], Germany } \\
\text { [53], Portugal [41], Hungary [63], } \\
\text { Spain [42] }\end{array}$ \\
\hline Anopheles maculipennis (s.l.) & D. repens and D. immitis & $\begin{array}{l}\text { Germany }[53,60] \text {, Austria [61], } \\
\text { Hungary [38] }\end{array}$ & Italy [40], Portugal [41] \\
\hline Aedes vexans & D. repens & $\begin{array}{l}\text { Czech Republic [62], Germany [60], } \\
\text { Hungary [38], Serbia [39], } \\
\text { Slovakia }[43,44]\end{array}$ & Italy [58], Turkey [50] \\
\hline Culex modestus & D. repens & Hungary [38] & Hungary [63] \\
\hline Aedes annulipes & D. repens & Hungary [38] & - \\
\hline Culiseta annulata & D. repens & Germany [60] & - \\
\hline Aedes caspius & D. repens & - & $\begin{array}{l}\text { Italy [58], Hungary [63], } \\
\text { Portugal [41], Serbia [39] }\end{array}$ \\
\hline Aedes sticticus & D. repens & Hungary [38], Serbia [39] & \\
\hline Coquillettidia richiardii & D. repens & Hungary [38] & Serbia [39], Italy [40] \\
\hline
\end{tabular}


infected specimens by human landing collections in this study indicates that members of both species complexes are potential zoonotic vectors of Dirofilaria spp. to humans. However, future studies might use recent molecular typing techniques [54-56] to identify the most likely vectors for Dirofilaria spp. in these species complexes.

The temporal prevalence of both Dirofilaria species followed the phenology of the mosquito abundance and was highest between July and September, which is in concordance with previous reports from Italy $[46,57]$, while other studies did not find a significant variation through the mosquito season [41, 58]. As discussed previously [46], this pattern is probably predominantly influenced by the local availability of Dirofilaria spp. infected dogs and therefore the abundance of the vector species is an important factor driving the spatial-temporal transmission risk of Dirofilaria spp. transmission.

Dirofilaria repens and $D$. immitis are considered to be transmitted by the same mosquito species [59]. European xenomonitoring studies revealed a variety of Dirofilaria spp. infection patterns for the screened mosquitoes, i.e. only $D$. immitis $[41,42,46,50]$, only $D$. repens [38, 60-62] or co-circulation as also observed in Moldova [16, 39, 40, 43, 44, 49, 53, 58, 63]. Nevertheless, the incidence of human dirofilariasis in Europe is significantly higher for infections with $D$. repens than with $D$. immitis [2]. The reasons for the dissimilarities in the epidemiology of both Dirofilaria species are unclear. While the pathology in the definitive hosts is well described [2], there is a lack of knowledge about the ecological differences in the intermediate host (e.g. differences in the extrinsic incubation period or host specificity). However, in this study, the number of days allowing the completion of the extrinsic incubation did not differ between the sites positive for $D$. repens or $D$. immitis. One possible explanation of the higher $D$. repens prevalence in Moldova might be the current spread of $D$. repens from eastern Europe to central Europe [10-16]. The most likely explanation for this observation is that $D$. repens infections in dogs are generally asymptomatic, while $D$. immitis infections cause more severe clinical symptoms and, thus, only the latter is recognized and treated to cure the infection $[64,65]$. Therefore, $D$. repens can spread unnoticed in the course of increasing dog travel for holidays or relocation $[64,65]$.

Finally, this study compared three different sampling methods for the monitoring of Dirofilaria spp. infected mosquitoes. Compared to the CDC traps, significantly fewer mosquito specimens were collected with human landing catches. Nevertheless, this method helped to identify additional potential Dirofilaria spp. vectors. Furthermore, the human landing collections provide important information about the human risk of Dirofilaria spp. infection. A large diversity of Dirofilaria spp.-infected mosquito species was recognized to feed on humans, underlining the high risk of infection in Moldova. At the same time, the results of the human landing catches support previous studies [66], which indicated that several mosquito species have a much broader host range compared to the classifications found in the literature, e.g. the detection of positive $D$. repens pools for Cs. longiareolata and Ur. unguiculata, which are expected to predominantly feed on birds or amphibians, respectively [27].

\section{Conclusion}

Although dirofilariasis has been diagnosed in Moldova both, in dogs and humans, solid information on the human risk of infection were missing. The temperature conditions are suitable to allow Dirofilaria spp. transmission within the entire country, which is supported by the detection of a wide distribution of Dirofilaria spp.positive mosquitoes with high infection rates in northern, central and southern Moldova. In conclusion, the low number of detected human cases probably does not reflect the current epidemiological situation of dirofilariasis in Moldova and a high prevalence in the local canine populations is expected. Therefore, physicians are advised to consider human subcutaneous and cardiopulmonary dirofilariasis in the differential diagnosis of subcutaneous and pulmonary nodules.

\section{Additional file}

Additional file 1: Table S1. Mosquitoes collected in Moldova between 2010 and 2015 with information on the coordinates of the sampling site, sampling date, mosquito species, pool size and Dirofilaria screening results. (XLSX $32 \mathrm{~kb})$

\section{Abbreviations}

95\% Cl: 95\% confidence interval; CDC traps: Centers for Disease Control miniature light traps; EIR: Estimated infection rate; qPCR: quantitative real-time PCR

\section{Acknowledgements}

We acknowledge the E-OBS dataset from the EU-FP6 project ENSEMBLES (http://ensembles-eu.metoffice.com) and the data providers in the ECA\&D project (http://www.ecad.eu).

Funding

This work was partially supported by EurNegVec COST Action TD1303.

Availability of data and material

All data are provided in the Additional file 1: Table S1.

\section{Authors' contributions}

Conceived and designed the study: TS, RL, ET. Collected the data: TS, HVT, LT, IT. Analysed the data: RL, TS. Wrote the manuscript: TS, RL, ET. All authors read and approved the final version of the manuscript.

Competing interests

The authors declare that they have no competing interests.

Consent for publication

Not applicable. 


\section{Ethics approval and consent to participate}

Both oral and written consent were obtained from all participants involved with human landing catches of mosquitoes. The study protocol was approved by the National Center of Bioethics of the Republic of Moldova based at the State University of Medicine and Pharmacy "Nicolae Testemitanu", Chisinau, Republic of Moldova (Reference number 192/01).

\section{Author details}

'Institute of Zoology, Academy of Sciences of Moldova, Chisinau, Moldova. ${ }^{2}$ Bernhard Nocht Institute for Tropical Medicine, WHO Collaborating Centre for Arbovirus and Hemorrhagic Fever Reference and Research, Hamburg, Germany. ${ }^{3}$ German Centre for Infection Research (DZIF), partner site Hamburg-Luebeck-Borstel, Hamburg, Germany.

\section{Received: 6 October 2016 Accepted: 25 November 2016} Published online: 03 December 2016

\section{References}

1. Canestri Trotti G, Pampiglione S, Rivasi F. The species of the genus Dirofilaria, Railliet \& Henry, 1911. Parassitologia. 1997:39:369-74.

2. Simón F, Siles-Lucas M, Morchón R, González-Miguel J, Mellado I, Carretón E, Montoya-Alonso JA. Human and animal dirofilariasis: the emergence of a zoonotic mosaic. Clin Microbiol Rev. 2012;25:507-44.

3. Poppert S, Hodapp M, Krueger A, Hegasy G, Niesen WD, Kern W, Tannich E. Dirofilaria repens infection and concomitant meningoencephalitis. Emerg Infect Dis. 2009;15:1844-6.

4. Sergiev VP, Supriaga VG, Morozov EN, Zhukova LA. Human dirofilariasis: diagnosis and the pattern of pathogen-host relations. Med Parazitol. 2009:3:3-6 (in Russian)

5. Fedianina LV. Human dirofilariasis in Russia. Med Parazitol. 2010;2:43-4 (in Russian).

6. Fedianina LV, Frolova AA, Pliushcheva GL, Chernyshenko Al, Morozov EN Rakova VM. Cases confirming the concept that the human being is a facultative host of Dirofilaria repens. Med Parazitol. 2011;4:37-8 (in Russian)

7. Fedianina LV, Shatova SM, Rakova VM, Shătanov VM, Lebedeva MN, Frolova AA, Morozov EN, Morozova LF. Microfilaraemia in human dirofilariasis caused by Dirofilaria repens Raiet et Henry, 1911. A case report. Med Parazitol. 2013;2:3-7 (in Russian).

8. Bronshteyn AM, Malyshev NA, Jarov SN, Fedianina LV, Frolova AA, Supriaga VG Luchshev VI. A first autochthonous human case of the long standing microfilaraemia due to Dirofilaria repens in Russia and a first experience of combined therapy of dirofilariasis repens. Epidemiol Infect Dis. 2013;3:47-52 (in Russian).

9. Pampiglione S, Rivasi F. Human dirofilariasis due to Dirofilaria (Nochtiella) repens: an update of world literature from 1995 to 2000. Parassitologia. 2000:42:231-54

10. Sałamatin RV, Pavlikovska TM, Sagach OS, Nikolayenko SM, Kornyushin W, Kharchenko VO, et al. Human dirofilariasis due to Dirofilaria repens in Ukraine, an emergent zoonosis: epidemiological report of 1465 cases. Acta Parasitol. 2013;58:592-8.

11. Kartashev V, Tverdokhlebova T, Korzan A, Vedenkov A, Simón L, Gonzalez-Miguel J, et al. Human subcutaneous/ocular dirofilariasis in the Russian Federation and Belarus, 1997-2013. Int J Infect Dis. 2015;33:209-11.

12. Auer $\mathrm{H}$, Susani M. The first autochthonous case of subcutaneous dirofilariosis in Austria. Wien Klin Wochenschr. 2008;20:104-6.

13. Cielecka D, Zarnowska-Prymek H, Masny A, Salamatin R, Wesolowska M, Golab E. Human dirofilariosis in Poland: the first cases of autochthonous infections with Dirofilaria repens. Ann Agric Environ Med. 2012;19:445-50

14. Tappe D, Plauth M, Bauer T, Muntau B, Dießel L, Tannich E, Herrmann-Trost P. A case of autochthonous human Dirofilaria infection, Germany, March 2014. Euro Surveill. 2014;19:2-4.

15. Matějů J, Chanová M, Modrý D, Mitková B, Hrazdilová K, Žampachová V, Kolářová L. Dirofilaria repens: emergence of autochthonous human infections in the Czech Republic (case reports). BMC Infect Dis. 2016;16:171.

16. Sulesco T, Volkova T, Yashkova S, Tomazatos A, von Thien H, Lühken R, Tannich E. Detection of Dirofilaria repens and Dirofilaria immitis DNA in mosquitoes from Belarus. Parasitol Res. 2016;115:3535-41.

17. Mănescu R, Bărăscu D, Mocanu C, Pirvănescu H, Mindriă I, Bălăşoiu M, Turculeanu A. Nodul subconjunctival cu Dirofilaria repens. Chirurgia. 2009;104:95-7 (in Romanian).
18. Lupșe M, Mircean V, Cavasi A, Mihalca AD. Recurrent subcutaneous human dirofilariasis due to Dirofilaria repens after surgical removal of the worm and anthelmintic treatment. Parasit Vectors. 2014;7 Suppl 1:P3.

19. Arbune M, Dobre M. Dirofilariasis - an emergent human parasitosis in Romania. Acta Parasitol. 2015;60:485-7.

20. Rozenbaum RS. A case of human dirofilariasis. Med Parazitol. 1970;39:620.

21. Lungu V, Cușnir V, Dumbrăveanu L. Description of the first case of human dirofilariasis registered in Moldova. In: Prisacari V, Zepca $V$, editors. Materialele congresului VI al igieniştilor, epidemiologilor şi microbiologilor din Republica Moldova. Chisinau: Gunivas; 2008. p. 287-9.

22. Novak VA, Drozdov AA, Gribonosov SN, Lapikova NV. Cases of parasitic invasion of the eyeball and adnexa in humans. In: XIII Ukrainian congress of ophthalmologists. Odessa: NAMS Ukraine; 2010. p. 302. in Russian.

23. Gudumac E, Plăcintă G, Vulpe V, Raducan M. Dirofilarioza subcutană prezentare de caz clinic. Sci Ann. 2011;14:17-9 (in Romanian)

24. Dumitru A. Răspîndirea helmintozelor la Canis familiaris în unele gospodării particulare de ovine. In: Cimpoies G, Marian G, Donica G, editors. Agricultura modernă - realizări și perspective. Chisinau: Universitatea Agrară de Stat din Moldova, Medicină Veterinară; 2013. p. 182-4.

25. Șuleșco TM, Toderas I, Toderas LG. Annotated checklist of the mosquitoes of the Republic of Moldova. J Am Mosq Control Assoc. 2013:29:98-101.

26. Schaffner F, Angel G, Geoffrey B, Hervy J-P, Rhaiem A, Brunhes J. The mosquitoes of Europe. Institut de Recherche pour le Développement/ Entente interdépartementale pour la démoustication du littoral (EID) Méditerrannée, Montpellier. 2001.

27. Becker N, Petric D, Zgomba M, Boase C, Madon M, Dahl C, Kaiser A. Mosquitoes and Their Control. 2nd ed. Heidelberg: Springer; 2010.

28. R Core Team. R: A language and environment for statistical computing. Vienna: R Foundation for Statistical Computing; 2015. http://www.R-project. org/ Accessed 1 Dec 2015.

29. Wickham H. ggplot2: elegant graphics for data analysis. New York: Springer; 2009

30. Wickham H. The split-apply-combine strategy for data analysis. J Stat Softw. 2011;40:1-29.

31. Bivand R, Lewin-Koh N. maptools: tools for reading and handling spatial objects, R package version 0.8-37. 2015. http://CRAN.R-project.org/package= maptools. Accessed 1 Apr 2016.

32. Hijmans RJ. raster: geographic data analysis and modeling, $\mathrm{R}$ package version 2.4-20. 2015. http://CRAN.R-project.org/package=raster. Accessed 1 Apr 2016.

33. Bivand $R$, Rundel $C$. rgeos: interface to geometry engine - open source (GEOS), R package version 0.3-19. 2016. http://CRAN.R-project.org/package= rgeos. Accessed 1 Apr 2016.

34. Genchi C, Rinaldi L, Cascone C, Mortarino M, Cringoli G. Is heartworm disease really spreading in Europe? Vet Parasitol. 2005;133:137-48.

35. Haylock MR, Hofstra N, Klein Tank AMG, Klok EJ, Jones PD, New M. A European daily high-resolution gridded dataset of surface temperature and precipitation. J Geophys Res Atmos. 2008;113:D20119.

36. Zhang B, Bilder C, Biggerstaff B, Schaarschmidt F. binGroup: evaluation and experimental design for binomial group testing. 2012. http://CRAN.R-project. org/package=binGroup. Accessed 1 Apr 2016

37. Walter SD, Hildreth SW, Beaty BJ. Estimation of infection rates in population of organisms using pools of variable size. Am J Epidemiol. 1980;112:124-8.

38. Kemenesi G, Kurucz K, Kepner A, Dallos B, Oldal M, Herczeg R, et al. Circulation of Dirofilaria repens, Setaria tundra and Onchocercidae species in Hungary during the period 2011-2013. Vet Parasitol. 2015;214:108-13.

39. Kurucz K, Kepner A, Krtinic B, Zana B, Foldes F, Banyai K, et al. First molecular identification of Dirofilaria spp. (Onchocercidae) in mosquitoes from Serbia. Parasitol Res. 2016;115:3257-60.

40. Cancrini G, Magi M, Gabrielli S, Arispici M, Tolari F, Dell'Omodarme M, et al. Natural vectors of dirofilariasis in rural and urban areas of the Tuscan region, central Italy. J Med Entomol. 2006;43:574-9.

41. Ferreira CA, de Pinho MV, Novo MT, Calado MM, Gonçalves LA, Belo SM, de Almeida AP. First molecular identification of mosquito vectors of Dirofilaria immitis in continental Portugal. Parasit Vectors. 2015:8:139.

42. Bravo-Barriga D, Parreira R, Almeida APG, Calado M, Blanco-Ciudad J, Serrano-Aguilera FJ, et al. Culex pipiens as a potential vector for transmission of Dirofilaria immitis and other unclassified Filarioidea in Southwest Spain. Vet Parasitol. 2016:223:173-80.

43. Bocková E, Rudolf I, Kočišová A, Betášová L, Venclíková K, Mendel J, et al. Dirofilaria repens microfilariae in Aedes vexans mosquitoes in Slovakia. Parasitol Res. 2013;112:3465-70. 
44. Bocková E, Iglódyová A, Kočišová A. Potential mosquito (Diptera:Culicidae) vector of Dirofilaria repens and Dirofilaria immitis in urban areas of Eastern Slovakia. Parasitol Res. 2015;114:4487-92.

45. Zielke E. Schutzmechanismen von Culiciden gegenüber Infestationen mit Filarien. Mitt Österr Ges Tropenmed Parasitol. 1993;15:149-56.

46. Capelli G, Frangipane di Regalbono A, Simonato G, Cassini R, Cazzin S, Cancrini $\mathrm{G}$, et al. Risk of canine and human exposure to Dirofilaria immitis infected mosquitoes in endemic areas of Italy. Parasit Vectors. 2013;6:60.

47. Lai CH, Tung KC, Ooi HK, Wang JS. Competence of Aedes albopictus and Culex quinquefasciatus as vector of Dirofilaria immitis after blood meal with different microfilarial density. Vet Parasitol. 2000;90:231-7.

48. Serrao ML, Labarthe N, Lourenco-de-Oliveira R. Vectorial competence of Aedes aegypti (Linnaeus 1762) Rio de Janeiro strain, to Dirofilaria immitis (Leidy 1856). Mem Inst Oswaldo Cruz. 2001;96:593-8.

49. Cancrini G, Scaramozzino P, Gabrielli S, Di Paolo M, Toma L, Romi R. Aedes albopictus and Culex pipiens implicated as natural vectors of Dirofilaria repens in central Italy. J Med Entomol. 2007;44:1064-6.

50. Yildirim A, Inci A, Duzlu O, Biskin Z, Ica A, Sahin I. Aedes vexans and Culex pipiens as the potential vectors of Dirofilaria immitis in Central Turkey. Vet Parasitol. 2011;178:143-7.

51. Paras $\mathrm{KL}, \mathrm{O}$ 'Brien VA, Reiskind $\mathrm{MH}$. Comparison of the vector potential of different mosquito species for the transmission of heartworm, Dirofilaria immitis, in rural and urban areas in and surrounding Stillwater, Oklahoma, U. S.A. Med Vet Entomol. 2014;28 Suppl 1:60-7.

52. Kuzmin Y, Varodi E, Vasylyk N, Kononko G. Experimental infection of mosquitoes with Dirofilaria repens (Nematoda, Filarioidea) larvae. Vestn Zoologii. 2005;39:19-24.

53. Kronefeld M, Kampen $H$, Sassnau R, Werner D. Molecular detection of Dirofilaria immitis, Dirofilaria repens and Setaria tundra in mosquitoes from Germany. Parasit Vectors. 2014;7:30.

54. Rudolf M, Czajka C, Börstler J, Melaun C, Jöst H, von Thien H, et al. First nationwide surveillance of Culex pipiens complex and Culex torrentium mosquitoes demonstrated the presence of Culex pipiens biotype pipiens/ molestus hybrids in Germany. PLoS One. 2013;8:71832.

55. Vogels CBF, van de Peppel LJ, van Vliet AJH, Westenberg M, Ibañez-Justicia A, Stroo A, et al. Winter activity and aboveground hybridization between the two biotypes of the West Nile virus vector Culex pipiens. Vector-borne Zoonotic Dis. 2015;15:619-26.

56. Lühken R, Czajka C, Steinke S, Jöst H, Schmidt-Chanasit J, Pfitzner W, et al. Distribution of individual members of the mosquito Anopheles maculipennis complex in Germany identified by newly developed real-time PCR assays. Med Vet Entomol. 2016:30:144-54.

57. Capelli G, Poglayen G, Bertotti F, Giupponi S, Martini M. The host-parasite relationship in canine heartworm infection in a hyperendemic area of Italy. Vet Res Commun. 1996;20:320-30.

58. Latrofa MS, Montarsi F, Ciocchetta S, Annoscia G, Dantas-Torres F, Ravagnan S, Capelli G, Otranto D. Molecular xenomonitoring of Dirofilaria immitis and Dirofilaria repens in mosquitoes from north-eastern Italy by real-time PCR coupled with melting curve analysis. Parasit Vectors. 2012;5:76.

59. Genchi C, Rinaldi L, Mortarino M, Genchi M, Cringoli G. Climate and Dirofilaria infection in Europe. Vet Parasitol. 2009;163:286-92.

60. Czajka C, Becker N, Jöst H, Poppert S, Schmidt-Chanasit J, Krüger A, Tannich E. Stable transmission of Dirofilaria repens nematodes, northern Germany. Emerg Infect Dis. 2014;20:328-31.

61. Silbermayr K, Eigner B, Joachim A, Duscher GG, Seidel B, Allerberger F, et al. Autochthonous Dirofilaria repens in Austria. Parasit Vectors. 2014;7:226.

62. Rudolf I, Šebesta O, Mendel J, Betášová L, Bocková E, Jedličková P, et al. Zoonotic Dirofilaria repens (Nematoda: Filarioidea) in Aedes vexans mosquitoes, Czech Republic. Parasitol Res. 2014;113:4663-7.

63. Zittra C, Kocziha Z, Pinnyei S, Harl J, Kieser K, Laciny A, et al. Screening blood-fed mosquitoes for the diagnosis of filarioid helminths and avian malaria. Parasit Vectors. 2015;8:16.

64. Genchi C, Kramer LH, Rivasi F. Dirofilarial infections in Europe. Vector-borne Zoon Dis. 2011:11:1307-17.

65. Genchi C, Mortarino M, Rinaldi L, Cringoli G, Traldi G, Genchi M. Changing climate and changing vector-borne disease distribution: the example of Dirofilaria in Europe. Vet Parasitol. 2011;176:295-9.

66. Börstler J, Jöst H, Garms R, Krüger A, Tannich E, Becker N, et al. Host-feeding patterns of mosquito species in Germany. Parasit Vectors. 2016;9:318.

\section{Submit your next manuscript to BioMed Central and we will help you at every step:}

- We accept pre-submission inquiries

- Our selector tool helps you to find the most relevant journal

- We provide round the clock customer support

- Convenient online submission

- Thorough peer review

- Inclusion in PubMed and all major indexing services

- Maximum visibility for your research

Submit your manuscript at www.biomedcentral.com/submit

) Biomed Central 